\title{
DIALEKTIKA MASYARAKAT BADUY DALAM MEMAKNAI REALITAS PEMILIHAN UMUM 2014
}

\author{
Karman \\ Balai Pengkajian dan Pengembangan Komunikasi dan Informatika (BPPKI) Jakarta, Badan Litbang SDM \\ Kementerian Komunikasi dan Informatika. Alamat : Jalan Pegangsaan Timur 19 B Menteng-Jakarta Pusat, Kode \\ Pos : 10320. Telp/Fax : (021) - 31922337. HP. +6285865888238, +6282188397473. \\ Email: karman@kominfo.go.id; karmansalim@gmail.com \\ Naskah diterima tanggal 9 September 2014, direvisi tanggal 29 Oktober 2014, disetujui tanggal 24 November 2014
}

\section{DIALECTIC OF BADUY COMMUNITY IN MEANING REALITY OF GENERAL ELECTION 2014}

\begin{abstract}
Baduy Community is very obedient to local rules/custom, e.g. lunang (sundanesse to express obedience to whoever the winner), and ngasuh rati, ngayak menak. Surprisingly, the voter number in Baduy have increased from 2013 to 2014. They have their own mechanism in determining leader, that is by deliberation among customary figures. The social-political changes make-up the result of their construction change toward reality. The issue in this study is how Baduy community (re-)construct general election. This one aims to understand Baduy's construction to electoral activities, their understanding to the obligation to participate in election, and the adaptation process of different realities (reality in Baduy and Reality in external). By harnessing the Social Construction of Reality introduced by Berger, and Social Adaptation System introduced by Giddens, this research show Baduy objectifies and participates in general elections as an obedience to the customary rules. Understanding about obligations to participate in election is legitimized by customary institution, regarding dualism of different structure, they must adapt theirselves to different realities.
\end{abstract}

Keywords: dialectic, subculture community, political reality, phenomenological research.

\begin{abstract}
Abstrak
Masyarakat Baduy Banten taat pada aturan adat (pikukuh karuhun), antara lain lunang (ikut yang menang), ngasuh rati, ngayak menak. Namun, jumlah pemilih pada masyarakat Baduy justru meningkat dari tahun 2013 sampai 2014. Mereka memiliki mekanisme tersendiri untuk menentukan pemimpin mereka. Perubahan sikap sosio-politik tersebut berkaitan dengan perubahan konstruksi masyarakat terhadap realitas politik sendiri. Permasalahan dalam penelitian ini adalah bagaimana masyarakat Baduy mengonstruksi, merekonstruksi realitas pemilihan umum (pemilu). Penelitian bertujuan ingin memahami konstruksi realitas masyarakat Baduy terhadap kegiatan pemilu, pemahaman mereka tentang kewajiban pemilu, proses adaptasi dari perbedaan realitas dan struktur sosial yang berada di luar mereka. Dengan menggunakan teori Konstruksi Realitas Sosial Berger dan teori Adaptasi Struktur Giddens, penelitian ini menunjukkan bahwa masyarakat Baduy mengobjektifikasi pemilu, berpartisipasi dalam pemilu sebagai wujud ketaatan pada aturan adat. Pemahaman kewajiban pemilu dilegitimasi oleh pejabat pada struktur adat (jaro pamarentah), dalam menghadapi dualisme struktur yang berbeda ini, mereka beradaptasi terhadap perbedaan realitas tadi.
\end{abstract}

Kata kunci: dialektika, masyarakat subkultur, realitas politik, fenomenologi. 


\section{PENDAHULUAN}

Pesta demokrasi berupa pemilihan umum (pemilu) 2014 diikuti 186,5 juta pemilih di seluruh Indonesia (Komisi Pemilihan Umum, 2014). Namun, tidak semua anggota masyarakat menggunakan hak politiknya atau golongan putih (golput). Pada pemilu sebelumnya, tren golput justru meningkat dari sebesar $6,4 \%$ pada pemilu legislatif (Pileg) 1999, hingga mencapai 29,1 $\%$ pada pileg 2009. Golput disebabkan selain karena awam tentang kelompok politik (Arianto, 2011) juga karena faktor budaya. Beberapa aturan adat masyarakat subculture (masyarakat yang memiliki praktik hidup, kepercayaan, dan nilai yang berbeda dari budaya dominan) di Indonesia kerap berbenturan dengan aturan-aturan negara termasuk aturan pemilu. Salah satunya adalah aturan pada masyarakat Baduy Kabupaten Lebak Banten. Mereka memiliki sikap ini yang didasari oleh nilai-nilai adat mereka sebut pikukuh adat atau pikukuh karuhun. Salah satu nilai adat adalah dalam bidang politik adalah lunang, atau milu $k a n u$ meunang, ikut pada yang menang, serta prinsip ngasuh rati, ngayak menak, artinya masyarakat Baduy harus menaati dan patuh kepada adat negara (Kurnia dan Sihabudin, 2010).

Namun, jumlah potensial pemilih pada masyarakat Baduy justru meningkat dari tahun 2013 sampai 2014. Pada Pilkada Lebak 14 November 2013, jumlah pemilih di desa Kanekes sebanyak 7.296 pemilih yang tersebar pada 13 Tempat Pemungutan Suara (TPS). Daftar Pemilih Tetap (DPT) untuk Pileg 2014 di Desa Kanekes sebanyak 7.436 pemilih dalam 15 TPS (Komisi Pemilihan Umum, 2014). Jadi, ada perubahan sikap politik masyarakat Baduy yang awalnya menolak karena alasan pikukuh karuhun menjadi menerima pemilihan umum. Peneliti berargumen bahwa perubahan sikap masyarakat Baduy erat kaitannya dengan konstruksi masyarakat terhadap realitas. Perbedaan dan perubahan konstruksi realitas masyarakat disebabkan proses internalisasi dan perbedaan struktur sosial dalam masyarakat. Realitas yang sama pun dapat dikonstruksi secara berbeda oleh individu/kelompok masyarakat.

Dalam sistem adaptasi sosial Giddens, pikukuh karuhun merupakan sebuah 'struktur' atau tata aturan dan sumber-sumber yang digunakan untuk memertahankan eksistensi suatu kelompok. Jika terjadi ketidaksesuaian antara realitas subjektif dengan realitas objektif, maka akan ada penyesuaian terhadap realitas melalui proses (re-)produksi, transformasi lingkungan sosial melalui interaksi sosial (Poole, et. al., 1996). Oleh karena itu, pertanyaan utama (research question) dalam penelitian ini adalah: bagaimana masyarakat Baduy mengonstruksi realitas politik (pemilu)?

Penelitian ini ingin menjelaskan konstruksi masyarakat Baduy terhadap realitas pemilihan umum serta menjelaskan perubahan konstruksi itu terjadi dari yang awalnya berprinsip milu $k a$ nu meunang kepada sikap menerima pemilu. Aspek yang akan dibahas untuk mencapai tujuan tersebut adalah (1) Bagaimanakah konstruksi masyarakat Baduy terhadap Pemilu? (2) Bagaimanakah masyarakat Baduy memahami kewajibannya sebagai bagian dari warga negara RI? dan (3) Bagaimanakah proses adaptasi dari perbedaan realitas dan struktur sosial yang berada di luar mereka?

Secara akademik, penelitian ini mengisi kurangnya penjelasan teoretis mengenai esensi pengalaman masyarakat Baduy dalam kegiatan demokrasi (pemilu) ditinjau dari ilmu komunikasi serta aspek yang berperan dalam proses konstruksi realitas tersebut. Masyarakat Baduy banyak dikaji dari sisi produk budayanya yang diterima secara turun temurun/taken for granted. Masalah yang diangkat antara lain tentang kearifan lokal (local wisdom) masyarakat Baduy, mitigasi bencana ala mereka, arsitektur bangunan, sistem pengobatan herbal, tataruang, proses transmisi pengetahuan, sistem atau teknik ladang mereka, dan sebagainya. Secara praktis, penelitian ini memberi masukan kepada agen sosialisasi (KPU, Kominfo, dan lain-lain) agar dalam merumuskan cara sosialisasi, kampanye kepada masyarakat adat menggunakan pendekatan partisipatoris untuk bersama-sama mengonstruksi realitas pemilu 
sesuai dengan yang direncanakan dalam agenda pembangunan demokrasi.

\section{LANDASAN KONSEP}

\section{Konstruksi Realitas Sosial}

Pandangan konstruksi realitas sosial menitikberatkan proses pembentukan realitas pada masyarakat. Manusia menjalin hubungan dengan lingkungannya sambil terus mengembangkan kemampuan adaptasinya dengan ekosistem yang ada (Berger, 1967). Realitas yang terbentuk berupa realitas objektif dan realitas subjektif. Pada realitas objektif, institusi formal maupun non formal menciptakan dan memertahankan atau mengubah tindakan dan interaksi manusia melalui definisi subjektifnya masing-masing. Objektivasi terjadi ketika manusia melakukan penegasan secara berulang-ulang pada definisi subjektif yang sama. Di tingkat yang lebih tinggi, manusia menciptakan dunia dalam makna simbolik yang universal, yaitu pandangan hidup yang menyeluruh, melegitimasi, dan mengatur bentuk-bentuk interaksi sosial serta memberi makna pada berbagai bidang kehidupan. Pikukuh karuhun berfungsi mengatur dan melegitimasi tata kehidupan masyarakat Baduy (Yulianti, 2006).

Proses institusionalisasi hadir melalui adat kebiasaan yang ada di masyarakat. Institusi adat berperan mengontrol masyarakat Baduy agar masyarakat menaati pikukuh karuhun. Institusionalisasi membutuhkan sebuah "legitimasi" yang bisa menjelaskan dan menjustifikasi proses institusionalisasi tersebut. Proses ini menghasilkan makna baru yang dibutuhkan untuk melayani makna yang sudah ada sebelumnya, dalam rangka membedakan setiap proses institusionalisasi di masyarakat. Legitimasi juga mengatur tatanan sosial dengan memberikan kewibawaan tertentu pada institusi untuk memberikan perintah secara praktis agar dilakoni oleh masyarakat (Berger, 1967). Bentuk legitimasi ini terlihat dari struktur adat masyarakat Baduy, yang melegitimasi kewenangan setiap fungsionaris adatnya. Karena institusi berada di luar diri manusia, maka keberadaannya hadir sebagai realitas eksternal yang tidak serta merta begitu saja dipahami oleh individu. Institusi menjadikan aktivitas manusia sebagai "objek" dengan memberikan tanda khusus pada dunia sosial. Maka dari itu, manusia membutuhkan proses tersendiri yang disebut eksternalisasi dan objektivasi. Eksternalisasi merupakan usaha pencurahan atau ekspresi diri manusia ke dalam dunia, sedangkan objektivasi adalah hasil yang telah dicapai, baik mental maupun fisik dari kegiatan eksternalisasi tersebut. Lewat proses objektivasi ini, masyarakat menjadi suatu realitas sui generis (Berger, 1967). Berger menyebut realitas ini sebagai momen yang bersifat dialektika, terus berlanjut menjadi jembatan untuk proses berikutnya, yaitu realitas subjektif.

Sedangkan pada realitas subjektif, masyarakat sangat berpotensi memenuhi dirinya sendiri (self-fulfilling) karena realitas itu bersifat plural. Proses ini terjadi melalui internalisasi, penyerapan kembali dunia objektif ke dalam kesadaran manusia. Setelah individu berhasil melakukan internalisasi sampai derajat 'kesadaran' tadi, secara otomatis ia menjadi anggota dari masyarakat. Proses yang membawa hal ini adalah sosialisasi atau introduksi (pengenalan) baik sosialisasi primer (keluarga) maupun sekunder (sekolah, teman, dan media) (Berger, 1967). Dari sudut pandang politik, dua tahap sosialisasi tersebut menjadi agen dalam sosialisasi politik. Menurut Nimmo, agen sosialisasi politik ada 5 (lima): keluarga, sekolah, peer groups, media massa, partai politik dan pemerintah (Nimmo, 1989).

Sosialisasi politik dapat dilakukan melalui kegiatan imitasi, instruksi, dan motivasi (Rush, 1983). Tujuannya adalah peningkatan partisipasi politik warga negara dalam menggunakan hak politiknya, yaitu ikut pemilu (BAPPENAS, 2010). Gejala peningkatan partisipasi politik masyarakat Baduy mengacu pada konsep Maslow didorong oleh (1) Kebutuhan fisiologis (physiological needs), seperti: sandang, pangan, dan lain-lain; (2) Kebutuhan keamanan (safety needs); (3) Kebutuhan sosial (social needs); (4) Kebutuhan kepercayaan diri (esteem needs); dan (5) 
Kebutuhan aktualisasi diri (self-actualization needs) (Maslow dalam Bryant, 2011).

Tata aturan sosial dalam masyarakat Baduy di(re-)produksi dan ditransformasi oleh institusi sosial yang ada, baik lembaga adat maupun institusi pemerintahan. Menurut Giddens, struktur sosial dan tata aturan yang dibuat sebenarnya membatasi perilaku anggotanya. Namun, di sisi lain aturan ini memungkinkan kita memahami dan berinteraksi dengan anggota lainnya (West and Turner, 2007). Ada dua struktur yang melingkupi masyarakat Baduy Luar, yaitu struktur adat dan struktur negara. Struktur berkaitan dengan proses pemberian sosialisasi dan legitimasi jika dikaitkan dengan teori Konstruksi Realitas Sosial. Sementara itu, strukturasi adalah proses adaptasi ketika realitas subjektif dan realitas objektif memiliki perbedaan nilai ketika struktur ini diinternalisasi oleh anggota masyarakat Baduy. Akibatnya, terjadi perubahan penggunaan sumber-sumber di dalam kelompok tersebut pada saat anggotanya melakukan eksternalisasi untuk kemudian membangun realitas objektifnya kembali.

\section{METODE PENELITIAN}

Paradigma penelitian ini adalah konstruktivisme atau interpretivisme (Henn, 2006) atau naturalistik yang berbeda dengan paradigma lainnya dalam hal epistemology (hubungan peneliti dengan objek penelitian), ontology (asumsi mengenai objek atau realitas), dan methodology (cara memeroleh pengetahuan) (Denzin dan Lincoln, 1994), dan berbeda juga dalam axiology (berkaitan dengan posisi value judgments, etika, moral peneliti) (Hidayat, 2002).

Theoretical perspectives penelitian ini menggunakan teori Social Construction of Reality atau teori Dialektika yang diperkenalkan oleh Berger dan Luckmann. Littlejohn dan Foss (2008) mengatakan bahwa konstruktivisme (dan konstruksionisme) menjadi salah satu ragam tradisi socioculture. Komunikasi pada tradisi ini menurut Craig (2007) diteorikan sebagai proses simbolik yang memroduksi tatanan sosiokultur bersama, bagaimana tatanan sosial (social order) sebagai sebuah fenomena makro (macrolevel phenomenon) diciptakan, disadari, dipertahankan, dan ditransformasikan melalui proses interaksi pada level mikro.

Strategi penelitian ini adalah phenomenological research. Pertanyaan mendasarnya (foundational question atau burning question) menurut Patton (2002) adalah untuk mengetahui esensi pengalaman. Dengan strategi ini, peneliti berusaha memeroleh refleksi fenomena realitas tentang pemilu secara sistematis, logis, dan koheren. Moustakas (1994) menjelaskan bahwa titik utama metode ini adalah pada ide dan esensi yang tak terbantahkan dari dunia alamiah atau realitas sehingga dibutuhkan pendekatan terhadap aktualitas dan potensialitas yang mengatur kehidupan subjek penelitian.

Pengumpulan data dilakukan di tiga dusun (Kaduketug, Marengo, dan Gajeboh) di Desa Kanekes-Kecamatan Leuwidamar, Kabupaten Lebak, Provinsi Banten. Masyarakat Baduy yang diteliti adalah Baduy Luar. Baduy Dalam pada waktu penelitian tidak bisa diakses karena ada ritual adat yang disebut bulan Kawalu yang berlangsung selama 3 (tiga) bulan: bulan Kasa (Kawalu Tembeuy/Kawalu Awal), bulan Karo/Kawalu Tengah, dan bulan Kawalu Tutug atau Kawalu Akhir. Mereka fokus pada pembersihan lahir dan batin salah satunya dengan puasa menurut tata aturan mereka.

Teknik pengumpulan dilakukan dengan (pertama) wawancara dialogik atau conversational. Wawancara dilakukan secara informal terhadap tiga orang warga. Subjek utamanya adalah jaro pamarentah (subjek 1) yang bernama jaro dainah. Alasan penulis memilihnya sebagai subjek penelitian karena kredibilitasnya yang secara administrasi dalam sistem pemerintahan nasional berada di bawah camat. Namun, secara adat ia di bawah pemimpin tertinggi adat yaitu pu'un. Oleh karena itu, ia memiliki pengetahuan tentang isu yang berkembang di luar masyarakat Baduy (tentang pemilu, dan sebagainya) serta mampu melihat dari perspektif adat Baduy. Jaro pemarentah merupakan penyeimbang antara sistem pemerintah nasional dengan 
sistem adat Baduy dan sebagai penghubung Baduy dengan masyarakat luar. Penjelasan jaro dainah dibantu dengan penjelasan dari panggiwa (setingkat aparat desa) dari Dusun Marengo dan seorang warga Baduy dari Dusun Gajeboh. Kedua observasiintertekstualitas. Peneliti mengumpulkan data/teks yang terkait dengan tema penelitian melalui observasi lapangan.

Tahapan analisis data dilakukan dengan: (1) Konstruksi makna lapangan yang bersumber pada wawancara; (2) Coding: proses mengelompokkan berdasarkan tema dan kategori dari data yang telah dikumpulkan. Pengelompokkan data dalam penelitian ini didasarkan pada konsep dari teori yang dirujuk. Analisis data ditekankan pada individual textual description dan structural description (semisal open coding, selective coding dalam Grounded Research). Textual description didapatkan dengan menganalisis transkrip wawancara yang telah dilakukan, sementara structural description dilakukan dengan menganalisis konteks dari catatan lapangan hasil observasi (Moustakas, 1994). Otentisitas dipenuhi dengan melakukan triangulasi sumber data pada ketiga subjek penelitian. Hasil wawancara disampaikan dalam tulisan ini secara naratif.

Penelitian ini memiliki beberapa keterbatasan. Seperti keterbatasan waktu penelitian sehingga dalam interaksi dan komunikasi bisa jadi ada keterbatasan. Karena itu pula, peneliti tidak bisa melakukan apa yang disebut oleh Saukko (2003) dengan istilah dialogic validity atau pemberian kesempatan kepada subjek untuk berkomentar terhadap studi ini sekaligus sebagai bentuk penghargaan peneliti terhadap dunia yang dikonstruksi masyarakat Baduy.

\section{PEMBAHASAN DAN HASIL PENELITIAN}

\section{Internalisasi (Realitas Subjektif)}

Masyarakat Baduy dilarang untuk sekolah formal. Kemampuan membaca, menulis, dan berhitung dianggap sudah cukup bagi warga. Jadi, tahapan sosialisasi utama hanya bersifat primer di level keluarga.
Motivasi untuk memenuhi kebutuhan fisiologis telah mengalahkan motivasi lainnya, termasuk menghadiri kegiatan sosialisasi pemilu yang diadakan KPUD. Subjek 3 lebih memilih bekerja ke kebun, dan subjek 2 lebih memilih memenuhi kebutuhan kayu bakar, menyadap aren, dan memasak tuak. Oleh karena itu, menurut subjek 1 isu tentang kesejahteraan ekonomi (seperti pertanian dan perdagangan) dan kesehatan, menjadi isu yang menarik dalam kampanye politik. Hal ini juga konsisten dengan harapannya kepada presiden terpilih selanjutnya.

Warga Baduy Luar memandang penting nilai kejujuran karena dapat menggambarkan nilai kesederhanaan dan kepercayaan antarsesama warga. Subjek 2 mengonstruksi nilai kejujuran sebagai bentuk perjanjian antara warga dengan Tuhan. Nilai-nilai adat tersebut dapat juga terlihat pada lunang. Peranannya sangat penting dalam menjaga kerukunan di Baduy. Nilai ini berlaku untuk urusan adat seperti pemilihan $P u$ 'un, tetapi lunang juga sering diterapkan pada urusan negara, seperti pemilu. Warga yang tidak memilih juga harus tetap menjalankan lunang. Tidak menjalankan lunang dianggap sebagai bentuk dosa terhadap Tuhan.

Tidak hanya aturan adat yang telah memengaruhi kesadaran warga Baduy Luar, tetapi juga aturan negara, seperti aturan pemilu. Pada aturannya jelas, untuk urusan negara merupakan legitimasi pemerintah Republik Indonesia termasuk pemerintah desa, sedangkan untuk urusan adat menjadi legitimasi lembaga adat. Lembaga adat tidak mencampuri urusan negara/pemerintah, begitupun pemerintah tidak mencampuri urusan adat. Sehingga aturan negara hanya berlaku bagi urusan negara saja, seperti pemilu, begitu pun aturan adat. Dalam proses internalisasinya, aturan adat tetap mengalahkan aturan negara. Misalnya ketika Pileg tanggal 9 April 2014 lalu akan diselenggarakan pula ritual adat Genek Kawalukan. Subjek 1 akan memrioritaskan mengikuti ritual adat tersebut ketimbang mengikuti pemilu. Selain itu, aturan adat juga lebih diprioritaskan ketimbang pemenuhan kebutuhan fisiologis. Ketika prosesi ritual 
adat berlangsung maka warga diwajibkan untuk meninggalkan semua aktivitasnya, termasuk aktivitas pemenuhan kebutuhan pokoknya.

\section{Institusionalisasi dan Legitimasi}

Lembaga melegitimasi sosialisasi politik. Institusi sosial yang bersifat formal dalam melaksanakan sosialisasi pemilu yaitu pemerintah RI, partai politik, dan media massa. Di situlah institusi adat dalam masyarakat Baduy berperan melakukan pengontrolan terhadap anggota masyarakatnya agar selalu menaati pikukuh karuhun. Dalam konteks pemilu, jaro dan panggiwa adalah agen dari lembaga adat untuk menjaga eksistensi struktur adat sambil menjalankan tugas dari pemerintah untuk menyosialisasikan pemilu. Jaro Dainah menuturkan bahwa dirinya sebagai kepala desa merasa wajib untuk menjalankan perintah KPUD sebagai bentuk kepatuhannya dengan peraturan negara. Institusi negara juga memunyai struktur tersendiri yang memiliki garis hirarki hingga ke level desa sehingga beragam tata aturan dari pemerintah pusat itupun harus dieksternalisasikan hingga ke level desa.

\section{Pola Sosialisasi Politik dari Institusi Sosial}

Terkait dengan konteks sosialisasi pemilu, masyarakat Baduy memiliki 2 (dua) struktur yang melingkupi realitas mereka. Struktur pertama adalah aturan adat atau amanat leluhur Pikukuh Karuhun yang dipegang teguh warga Baduy. Sedangkan struktur kedua adalah peraturan perundangundangan yang terkait dengan pemilu beserta peraturan turunannya, yang mengacu pada Undang-Undang Republik Indonesia Nomor 8 Tahun 2012 tentang Pemilihan Umum Anggota DPR, DPD, dan DPRD. Struktur adat dilegitimasi oleh lembaga adat yang dipimpin oleh Pu'un, beserta Jaro sebagai jajarannya, dan Panggiwa sebagai ujung tombak ke masyarakat. Sementara struktur peraturan pemilu dilegitimasi oleh KPU, KPUD, dan PPS beserta aparat pemerintahan desa.
Subjek 1 memberikan konstruksi bahwasanya negara membuat legitimasi melalui undang-undang, sedangkan lembaga adat melegitimasi melalui aturan adat, seperti: tidak memaksa warga Baduy untuk menggunakan hak suaranya (kembali ke masing-masing individu); tidak ada sanksi bagi yang tidak memilih; lembaga adat tidak berpihak pada caleg/parpol manapun, lembaga adat juga memilih; tidak boleh ada penempatan TPS di Baduy Dalam, 15 TPS tersebut hanya boleh di Baduy Luar, jika warga Baduy Dalam yang ingin menyoblos maka tinggal menuju ke TPS yang terdekat di Baduy Luar; melarang kampanye terbuka karena dapat memicu perpecahan; Pu'un tidak membolehkan masyarakat Baduy mengikuti Pemilu. Pu'un dipercaya oleh warga Baduy memiliki ilmu kebatinan, wangsit, ataupun kharisma yang dapat dipergunakan untuk memberikan keputusan, wejangan, dan ramalan kepada warga. Beragam konstruksi yang dikeluarkan oleh $P u$ 'un wajib ditaati karena ia memiliki kekuasaan untuk melegitimasi pada masyarakat Baduy.

\section{Eksternalisasi Sosialisasi Politik (Realitas Objektif)}

Eksternalisasi adalah usaha pencurahan atau ekspresi diri warga Baduy ke dalam dunia, baik dalam kegiatan mental maupun fisik (Berger, 1967). Hal ini sudah menjadi sifat dasar manusia yang selalu ingin mencurahkan diri ke tempat di mana ia berada. Dalam kegiatan Pileg 2014, masyarakat Baduy, menurut Subjek 1, sudah mengikuti pemilu sejak 1996, 1998, 1999, 2004, dan 2008. Lembaga adat mendorong warganya untuk menggunakan hak suaranya dan mengutus seseorang untuk bertanya langsung ke pihak yang terkait dengan pemilu seperti KPU dan PPK. Hal ini menunjukkan rasa antusias masyarakat Baduy Luar antusias untuk terlibat aktif dalam kegiatan pemilu.

Sebagai gambaran, masyarakat Baduy Luar mengikuti simulasi pemungutan suara yang diadakan oleh pemerintah Desa Kanekes. Sementara itu, masyarakat Baduy Dalam tidak mengikutinya. Warga yang ikut simulasi akan diberikan hadiah bagi yang 
berhasil menyoblos secara cepat dan tepat. Pada acara itu pula, pemerintah melakukan sosialisasi ke masyarakat mengenai proses dalam pemilu. Kegiatan ini juga didukung oleh lembaga adat (tidak melarang warga Baduy Luar untuk ikut pemilu). Namun, keikutsertaan mengikuti pemilu tetap dikembalikan ke masing-masing individu.

Menjelang pemilu, Jaro Pamarentah dan pamong desa menjelaskan kewajiban memilih tanggal 9 April 2014. Tokoh adat/masyarakat bersama pemerintah desa dan RT mengundang, mengajak warga yang tercantum dalam DPT untuk menghadiri rapat/pertemuan. Di sana, jaro pamarentah menjelaskan perihal pemilu. Kemudian kepala keluarga menyosialisasikan informasi dari rapat RT kepada anaknya.

Sementara itu, PPS (Panitia Pemungutan Suara) dan PPK (Panitia Pengawas Kecamatan) menjelaskan visi PPS dan PPK kepada warga. Pihak desa juga menjelaskan tanggungjawabnya untuk menyukseskan pemilu. Sebelumnya, kecamatan dan desa telah mendata DPT. Kemudian, calon anggota legislatif (caleg) masuk ke dusun-dusun membawa gambar dirinya dan menjelaskan bagaimana cara memilih dirinya. Peran lembaga adat menekankan kebebasan dalam memilih dan ketidakberpihakan. Larangan untuk ikut dalam pemilu tidak terlalu menonjol, yang penting adalah terciptanya lingkungan lestari dan aman.

\section{Objektivasi Realitas}

Objektivasi, yaitu hasil yang telah dicapai, baik mental maupun fisik dari kegiatan eksternalisasi manusia tersebut (Berger, 1967). Itu menghasilkan realitas objektif yang bisa jadi akan menghadapi si penghasil itu sendiri sebagai suatu aktivitas yang berada di luar dan berlainan dari manusia yang menghasilkannya. Pola-pola objektivasi yang menjadi karakter khas masyarakat Baduy terkait struktur masyarakat yang terbentuk di dalamnya. Aturan dan nilainilai adat dipatuhi dan dijalankan oleh seluruh warga Baduy. Nilai adat dalam konteks politik adalah antara lain Lunang.
Pada masyarakat Baduy dan masyarakat subkultur secara umum, supremasi hukum adat yang diketuai oleh kepala adat (Pu'un) lebih dijunjung tinggi ketimbang hukum dari pihak pemerintah. Masyarakat Baduy lebih memrioritaskan mengikuti genek kawalukan (ritual adat) daripada mengikuti pemilu jika waktunya bersamaan. Proses warga Baduy Luar mengenali sistem politik kemudian menentukan persepsi dan reaksi mereka terhadap gejala-gejala politik. Adanya sosialisasi politik melatih warga Baduy Luar dalam memasukkan nilai-nilai politik yang berlaku di dalam sebuah sistem politik. Inilah proses objekitivasi.

Selain itu, sosialisasi politik juga bertujuan untuk memelihara sistem politik dan pemerintahan yang resmi. Sosialisasi politik yang dilakukan ketika masih kanakkanak (primer) didapatkan dari keluarganya, yaitu dilakukan oleh ayah sebagai kepala keluarga kepada anak-anaknya. Sosialisasi sekunder biasanya diperoleh dari sekolah, teman, media (khususnya media below the line), dan tokoh adat, pamong desa (panggiwa) atau lembaga pemerintah (KPU).

Di masyarakat Baduy, sosialisasi dari KPU dilakukan melalui undangan untuk menghadiri acara simulasi penyoblosan oleh KPU. Perangkat desa telah menyebarkan ke seluruh kampung dengan jumlah sekitar 7000 pemilih. Menurut Subjek 1, instruksi penyoblosan diarahkan dengan cara mengarahkan warga Baduy untuk melihat tulisan, gambar, ataupun warna yang akan dipilih.

Dalam masyarakat Baduy, upaya untuk mengatasi kendala partisipasi warga Baduy dalam pemilu, yaitu dengan adanya Petugas Renteng. Petugas ini lebih pada level teknis menulis, warga datang ke TPS dan memilih secara benar petugas pendamping dirasa memiliki manfaat untuk mengurangi surat suara tidak sah (blanko). Namun, petugas pedamping ini sering dicurigai netralitasnya untuk mengarahkan ke salah satu pertai tertentu. Warga Baduy Luar meniru tingkah laku individu lainnya yang dilakukan untuk mengatasi beberapa keterbatasan instruksi, seperti pada simulasi pemungutan suara untuk Pileg 2014 yang diselenggarakan oleh KPUD 
Provinsi Banten bersama KPU Kabupaten Lebak di halaman depan rumah Jaro Dainah (Kaduketug) dengan melibatkan pihak kecamatan, PPK, Kelompok Penyelenggara Pemungutan Suara (KPPS), dan PPS.

Untuk urusan pemerintahan RI, lembaga adat tidak mencampurinya dengan menyerahkan sepenuhnya kepada pemerintahan negara (melalui KPUD dan kepala desa). Apabila ada intervensi, lembaga adat tidak terlalu memaksakan atau cenderung menerima keputusan pemerintahan negara, misalnya ketika lembaga adat mengusulkan untuk perubahan lokasi dan jumlah TPS, KPUD tetap memutuskan 15 lokasi TPS dan lembaga adat menerimanya. Pada pemilihan sebelumnya ada 13 TPS. Sedangkan untuk urusan adat, pemerintahan RI (KPUD) tidak mencampurinya dengan menyerahkan sepenuhnya kepada lembaga adat.

Berbagai realitas yang terjadi, baik itu hasil interaksi antara sesama warga Baduy dalam aktivitas kesehariannya, maupun hasil interaksi dengan warga dari luar Baduy, akan membentuk suatu realitas objektif. Realitas objektif yang terbentuk dari kegiatan eksternalisasi, akan membentuk objektivasi warga terhadap konstruksi realitas tersebut. Objektivasi yang terbentuk, baik secara mental maupun fisik dari kegiatan eksternalisasi, akan kembali ditangkap sebagai gejala internal yang memengaruhi tingkat kesadaran warga. Realitas yang terbentuk, bahkan tertanam dalam kesadaran warga inilah yang disebut realitas subjektif, sedangkan prosesnya dinamakan internalisasi. Tidak berhenti di sini saja, realitas subjektif yang telah tertanam akan kembali dipancarkan kepada lingkungan sosialnya melalui aktivitas sosialisasi. Warga Baduy Luar pun turut berperan menjadi agen sosialisasi dalam membentuk realitas objektifnya. Begitupun seterusnya hingga membentuk sebuah proses dialektika, proses yang cyclic, sirkular. Inilah menjadi alasan juga mengapa teori Konstruksi Realitas Sosial yang diperkenalkan oleh Berger dikenal juga dengan teori Dialektika.

Pada konteks pemilihan, baik itu pemilu ataupun pemilihan pu'un, prinsip lunang memainkan peranan penting dalam mencegah terjadinya kekacauan atau konflik. Lunang menjadi sebuah instruksi yang tidak tertulis yang harus dijalankan warga Baduy. Subjek 1 menegaskan bahwa lunang tidak hanya dapat diterapkan dalam aturan adat Baduy, melainkan juga dapat diterapkan dalam aturan negara seperti pemilu. Ia membantah pandangan yang mengatakan bahwa lunang merupakan bentuk golput atau tidak memilih dari warga Baduy, tetapi lunang tetap menginstruksikan warga Baduy untuk tetap memilih. Lunang mengharuskan warga untuk tetap legowo/ikhlas mematuhi dan menerima siapapun pemimpin yang menang, baik itu untuk urusan negara maupun untuk urusan adat. Lunang lebih dipertegas lagi dalam konteks pemilihan adat, setiap warga Baduy yang menolak hasil keputusan lembaga adat dalam pemilihan adat dianggap berdosa.

"Itu mah kalau urusan di luar itu urusan desa semuanya, gak ikut campur ke urusan adat. Tapi tetep desa harus koordinasi. Satu contoh kemaren, begitu hasil penghitungan gimana sama calon yang mana yang menang, yang menang nomor tiga itu, kade itu legowo. Satu contoh Lunang itu begini, tadi mah orang mah Lunang, milu kanu meunang, yang menang itu ikuti aturan mana kan gitu." (Hasil Wawancara dengan subjek 1, Rabu tanggal 02 April 2014, di Dusun Kaduketug, Desa Kanekes, Kecamatan Leuwidamar, Kabupaten Lebak, Provinsi Banten).

Subjek 1 menyadari bahwa lunang merupakan salah satu bentuk penerapan demokrasi. Lunang dalam konteks pemilu berarti setiap warga Baduy harus mengikuti segala keputusan pemimpin yang menang dalam pemilu, termasuk warga yang tidak ikut memilih, juga harus tetap mematuhinya. Melalui kesadaran diskursif, warga Baduy Luar dapat mengartikulasikan tujuan dan perilaku pribadinya melalui aturan negara. Aturan ini bersifat tertulis sehingga mudah dibahasakan. Namun, pada aturan adat, tidak semua warga mampu mengartikulasikannya. Karena aturan ini lebih bersifat lisan (tidak tertulis), tidak semua warga mampu mengartikulasikan tujuan atau perilaku pribadinya melalui aturan ini. Oleh karena itu, dengan kesadaran praktis, warga secara sadar mengungkapkannya melalui tindakan atau perasaan tertentu. Bentuk kesadaran praktis lainnya seperti pelarangan adanya sekolah 
seperti yang telah dijelaskan sebelumnya dan pelarangan kampanye terbuka di Baduy.

\section{Penyesuaian Realitas: Dialektika Konstruksi Realitas Sosial dan Adaptasi Struktur}

Era informasi membawa perubahan besar bagi struktur masyarakat sehingga membutuhkan adaptasi terhadap pelbagai kondisi. Kondisi tersebut tercapai ketika mereka melakukan eksternalisasi tahap berikutnya dari tahap objektivikasi sebelumnya. Ini terkait dengan proses konstruksi realitas yang tidak linear alias selalu berdialektika secara cyclic. Hal ini terlihat di masyarakat Baduy Luar yang telah banyak menggunakan teknologi modern. Berdasarkan pengamatan di lapangan sudah banyak peralatan yang berasal dari masyarakat luar. Proses penyesuaian realitas ini dimulai oleh golongan muda, meski awalnya sempat dilarang oleh golongan tua atau kokolot.

Pelarangan tersebut adalah bentuk objektivasi yang dialami oleh golongan muda terhadap apa yang diinternalisasi oleh golongan tua. Ini terjadi lantaran adanya sebuah perilaku baru ketika masyarakat dihadapkan pada realitas objektif yang berbeda dengan realitas subjektif. Perilaku ini membentuk sebuah diskursif. Perubahan (change) struktur bisa terjadi jika semakin banyak aktor atau agen yang mengadopsi kesadaran diskursif, yaitu, manakala si agen "mengambil jarak" dari struktur, dan melakukan sesuatu tindakan dengan mencari makna/nilai dari tindakannya tersebut. Hasilnya bisa berupa tindakan yang menyimpang dari rutinitas atau kemapanan, dan praktis telah mengubah struktur tersebut. Dari sini memunculkan sebuah objektivasi baru terhadap kesadaran diskursif ini.

Fenomena di atas terkonstruksi dari penuturan Subjek 2 yang mewakili lembaga adat, soal bagaimana golongan tua mengobjektivasi pola agensi golongan muda. Konstruksi tutur ini dibangun berdasarkan penggunaan teknologi. Dari sini bisa terlihat jika, golongan muda dalam masyarakat Baduy lebih terbuka terhadap segala realitas dari luar konstruksi stuktur adat. Mereka diizinkan untuk menggunakan peralatan hidup berteknologi dari luar mereka, asalkan tetap bisa menghormati lembaga adat tersebut. Warga Baduy Luar berubah dalam memandang realitas politik negara. Meskipun dalam realitas adat mereka tidak ada proses pemilihan pemimpin secara kolektif (voting), namun mereka mampu mengeksternalisasi realitas demokrasi dalam hal kebebasan memilih pemimpin rakyat dalam institusi negara. Proses ini melibatkan objektivasi terhadap realitas yang juga terdapat di luar struktur sosial mereka.

Menurut Subjek 1, masyarakat Baduy kini telah bisa menilai bagaimana pemimpin yang layak dipilih dalam realitas struktur demokrasi. Biasanya calon pemimpin yang sudah dikenal sebelumnya lebih mudah diterima oleh masyarakat Baduy. Dalam tuturannya yang lain tergambar bahwa indikator pemimpin yang layak dipilih itu berdasarkan keunggulan komparatif tertentu. Dalam hal ini perilaku yang baik, bebas korupsi, dan menepati janji politiknya. Indikator-indikator ini mereka ambil dari nilai-nilai pikukuh karuhun yang selama ini telah terinternalisasi.

Pemilu di masyarakat Baduy tidak memiliki dampak besar karena masyarakat Baduy berbeda dengan masyarakat luar yang besar jumlahnya sehingga dianggap dapat menentukan realitas pemerintahan negara. Konstruksi masyarakat Baduy menganggap diri mereka tidak diberikan amanat untuk meramaikan/membangun negara tetapi ditugaskan untuk memertahankan pikukuh karuhun. Jika ini dilanggar maka pasti ada guncangan ke pihak adat bahkan dapat merusak tatanan dan ketenteraman wiwitan. Kepercayaan wiwitan tidak boleh memihak siapapun, hanya mendoakan saja.

Dalam sejarahnya, wiwitan tidak bisa berpihak pada satu partai, golongan atau pihak manapun, karena bila memihak goncangannya akan sangat besar pada masyarakat, mengganggu keharmonisan, kebersamaan, persatuan dan kesatuan adat Baduy dalam melaksanakan pikukuh karuhun atau amanat leluhur (Kurnia dan Sihabudin, 2010). Pikukuh Karuhun ini adalah suatu aturan atau buku manual yang menerangkan 
bagaimana tujuan bisa dicapai. Untuk menegakkan aturan, perlu ada berbagai sumber daya, mengacu pada kekuasaan yang digunakan oleh agen ke dalam interaksi kelompoknya.

Pada praktik pemerintahan di struktur adat Baduy, suara warga Baduy diwakili oleh tokoh-tokoh adat yang ada di lembaga adat ketika pemilihan $p u$ 'un (ini dikenal dengan Sistem Noken). Tetapi ketika pemilu, pendelegasian suara seperti itu tidak berlaku, yang berlaku adalah satu suara untuk satu warga Baduy. Pengalaman hidup dan aturan terdahulu terkait pelarangan-pelarangan tersebut membuat individu menjadi mampu memonitor dan memutuskan tindakan atau perilakunya. Inilah yang menurut teori Strukturasi Adaptif Giddens disebut sebagai refleksivitas, yaitu kesadaran atau kemampuan yang memungkinkan diri agen memonitor tindakan dan perilakunya. Praktiknya kesadaran ini memiliki dua level, yaitu kesadaran diskursif dan kesadaran praktis (West and Turner, 2007).

Apa yang Gidden katakan sebagai refleksivitas adalah suatu bentuk "pengetahuan". Refleksivitas adalah sebuah episteme bagi anggota masyarakat Baduy. Dasar-dasar pengetahuan ini dapat digali dan dirumuskan dengan menggunakan analisis fenomenologis seperti dalam penelitian ini. Analisis ini atau yang dikenal dengan pengalaman subjektif kehidupan sehari-hari dianggap metode paling baik dalam mencari dasar-dasar pengetahuan dalam kehidupan sehari-hari. Fenomenologi untuk mengkaji perspektif konstruksi realitas sosial, akan sepenuhnya deskriptif, 'empiris' namun tidak 'scientific' seperti umumnya dalam empirical science (Berger, 1966). Berger dan Luckmann membedakan dengan tegas antara phenomenological analysis untuk kehidupan sehari-hari dan sociological analysis untuk masyarakat. Keduanya 'empirical', kendatipun tak persis sama. Ketika fenomenologis bersifat 'egological', maka social scientific method bersifat 'cosmological' (Eberle, 1992).

Dalam perspektif Konstruksi Realitas Sosial ada penekanan proposisi dalam kaitan dengan pengetahuan sebagai budaya (knowledge as culture). Pertama, knowledge is socially determined. Struktur sosial akan menciptakan pengetahuan. Proposisi ini menegaskan bahwa semua pengetahuan berkembang, berubah seiring dengan kondisi sosial dan material. Di sinilah ketika dalam penjabaran analisis di atas, terdapat pengetahuan dapat memicu terjadinya sebuah tindakan baru (fresh act). Menurut Gidden, fresh act dilakukan kelompok sosial berdasarkan hal-hal yang telah lampau, tentu di sini mengacu pada aspek pengalaman. Pemahaman masa lalu menjadi rujukan kepada pemahaman mengenai tata aturan dan sumber-sumber seperti apa yang dibutuhkan untuk menjalankan sistem sosial. Hal yang menjadi asumsi dasar adalah bahwa ketika kita berkomunikasi dengan orang lain, sebenarnya kita sedang membuat awalan untuk tata aturan baru ataupun harapan kepada hal tersebut, dengan mengangkat tata aturan lama, atau dengan menegaskan ulang aturan yang telah lama ada (West and Turner, 2007).

Kedua, reality is socially constructed by knowledges. Proposisi ini menekankan bahwa realitas sosial adalah sesuatu yang dihasilkan dan dikomunikasikan. Fokus dalam proposisi ini adalah pengetahuan dibentuk oleh realitas sosial. Ini menjadi tumpuan utama masyarakat Baduy yang menjadikan lembaga adat sebagai penentu konstruksi pengetahuan masyarakatnya. Tidak seperti masyarakat perkotaan yang diperbolehkan untuk memeroleh pengetahuan dari sekolah dan media, maka pada masyarakat Baduy pengetahuan diobjektivasi secara turuntemurun melalui agen sosialisasi keluarga. Oleh sebab itu, institusi adat memiliki karakter untuk melakukan pengontrolan pengetahuan. Di situlah anggota masyarakat selalu menaati pikukuh karuhun. Dalam perspektif teori Adaptasi Struktur Giddens, pikukuh karuhun lebih tepat sebagai "struktur" yang sekaligus menjadi "aturan" bagi masyarakat Baduy. Sementara lembaga adat adalah insitusi sosial yang memberikan legitimasi, agar masyarakatnya merekonstruksi realitasnya sesuai internalisasi yang kongruen dengan pikukuh karuhun, dalam perspektif Berger. 
Di sinilah kunci dari konstruksi yang mereka bangun terkait pemilu meski berasal dari struktur negara. Karena ketika lembaga adat memberikan konstruksi yang positif soal pemilu, anggota masyarakatnya juga akan merekonstruksi secara positif pula. Legitimasi dari institusi adat akan memberikan kekuasaan kepada masyarakatnya. Bentuk kekuasaan menurut Gidden yang terdapat dalam masyarakat Baduy adalah: (1) Kekuasaan koersif, berupa sanksi yang diberikan oleh lembaga adat seperti pemberian hal negatif kepada anggota yang tidak mengikuti struktur sesuai kesepakatan; (2) Kekuasaan referensi yang ditentukan oleh sumber-sumber yang memandu keputusan komunikasi, dalam hal ini jaro pamarentah; (3) Kekuasaan legitimasi, persepsi di mana lembaga adat Baduy memiliki kemampuan untuk mendesak pengaruhnya karena posisi ataupun jabatan sosial di struktur pemerintahan; dan (4) Kekuasaan ahli, mengacu pada kemampuan para jaro dalam mendesak pengaruh kepada lainnya berdasarkan pengetahuan dan ekspertis yang dimilikinya (West and Turner, 2007).

Dalam hal pola sosialisasi politik, semua agen terlibat dalam praktik ini, kecuali media. Karena praktik sosialisasi terkena batasan dari bentuk institusi sosial dan struktur itu sendiri. Terkait dengan hal ini, versi awal teori Konstruksi Realitas Sosial memang belum memasukkan unsur tentang media massa sebagai socialization agent dan agent of change dalam dinamika kehidupan sosial. Sehingga memiliki nilai approriateness yang kuat untuk penelitian ini. Tak heran jika teori ini dianggap cuma bekerja dalam level interaksi komunikasi interpersonal karena di sinilah proses dialektika yang dimaksud dalam teori itu terjadi. Lebih jauh lagi, Gergen menganggap social construction of reality kurang tepat dijadikan sebagai teori, namun lebih kepada movement atau tradisi tersendiri (Gergen dalam Littlejohn dan Foss, 2011). Karena dengan datangnya sosio-konstruksionis, kita memandang komunikasi hanya sebagai sebuah "perspektif" ketimbang "subject matter". Sebab, komunikasi hanyalah bagian proses yang dilakukan untuk mengonstruksi realitas. Jika komunikasi dipandang hanya sebagai perspektif dari sosio kontruksionis, maka akan ada perspektif lainnya yang non komunikasi turut hadir pula di dalam tradisi ini.

Meski nilai appropriatenessnya cukup baik, teori Konstruksi Realitas Sosial tidak mampu menjawab ketika masyarakat Baduy dihadapkan pada dua bentuk realitas yang berbeda. Hal ini menuntut mereka untuk melakukan dua bentuk objektivasi juga, sehingga memunculkan apa yang disebut fresh act tadi. Namun, dalam masyarakat dengan institusionalisasi dan legitimasi yang ketat seperti ini, fresh act dianggap mengancam bagi aturan dan institusi adat. Karena institusi adat memunyai peran untuk memberikan legitimasi terhadap aspek-aspek realitas untuk diinternalisasi oleh anggota masyarakatnya. Cara memertahankan eksitensi lembaga adat sebagai institusi sosial masyarakat Baduy, adalah dengan mencegah agar legitimasi yang dilakukannya terhadap segala aturan, tidak mengalami penurunan derajat legimatenya seiring waktu. Fungsifungsi yang dipergunakan untuk memertahankan hal ini, mengambil dari unsur-unsur yang sifatnya metafisika, misalnya informasi melalui wangsit, balasan terhadap pelanggaran sumpah, dan lainnya. Hal ini diciptakan agar proses institusionalisasi tidak terganggu oleh segala hal yang hasil objektivasi dari realitas di luar struktur mereka, yang menjadi ancaman untuk terjadinya perubahan. Ketika realitas objektif yang didapat oleh masyarakat Baduy melalui perwakilan lembaga adatnya di pemerintahan (sebagai kades) tidak bersesuaian dengan aturan lembaga adat mereka, maka mereka akan melakukan objektivasi ulang dengan membentuk tekanan-tekanan tertentu kepada struktur pemerintah negara Indonesia.

\section{PENUTUP}

\section{Simpulan}

Terkait dengan konstruksi realitas masyarakat Baduy terhadap pemilu, masyarakat Baduy memandang bahwa pemilu 
sebagai kewajiban dalam memenuhi aturan dalam struktur negara. Kewajiban ini sudah mendapat legitimasi dari institusi adat sehingga masyarakat Baduy terdorong berpartisipasi dalam kegiatan pemilu. Aturan dalam struktur adat membentuk institusi sosial yang melegitimasi terhadap realitas seperti apa yang boleh diinternalisasi oleh anggota masyarakatnya.

Masyarakat Baduy sebagai warga negara RI memahami kewajiban pemilu karena adanya legitimasi dari jabatan struktur adat di sana yaitu kepala desa (jaro pamarentah). Penggunaan kekuasaan lembaga adat Baduy berkontribusi besar dalam kegiatan pemilu.

Dalam menghadapi dualisme struktur yang berbeda ini satu sisi struktur adat masyarakat Baduy, dan sisi lain struktur negara, menciptakan kondisi di mana masyarakat Baduy harus beradaptasi terhadap perbedaan realitas tadi. Sesuatu yang berasal dari luar yang baru (fresh act) dianggap mengancam eksistensi aturan dan lembaga adat. Jika aturannya terganggu, fungsi legitimasinya juga terganggu, kemudian eksistensi dari proses institusionalisasi itupun juga terganggu. Demi mendukung penguatan eksistensi struktur terhadap beragam kesadaran diskursif yang bisa memicu fresh act yang bertentangan, lembaga adat Baduy melakukan penyesuaian (adaptasi) terhadap realitas yang mereka objektivasi. Ketika realitas objektif yang didapat oleh masyarakat Baduy melalui perwakilan lembaga adatnya di pemerintahan tidak bersesuaian dengan aturan mereka, mereka melakukan tindakan objektivasi ulang dengan membentuk tekanan-tekanan tertentu pada struktur pemerintah negara Indonesia.

Penelitian ini bisa memberikan implikasi teori yang berusaha untuk meningkatkan nilai heuristik dari teori Konstruksi Realitas Sosial Berger (1967), ketika dipakai untuk menelaah realitas fenomenologis dalam masyarakat seperti masyarakat Baduy ini. Dari poin di atas, maka terlihat bahwa nilai parsimony dari perspektif Konstruksi Realitas Sosial dipertanyakan kembali dalam penelitian ini. Oleh karena itu, perspektif Adaptasi Struktur Giddens bisa menjembatani ketika masyarakat seperti suku Baduy ini harus memeroleh dua jenis realitas yang bertentangan untuk diobjektivasi melalui kesadaran diskursif untuk kemudian memunculkan realitas baru (fresh act).

Versi awal dari teori Konstruksi Realitas Sosial untuk penelitian dalam masyarakat, memiliki nilai approriateness yang cukup kuat, namun nilai parsimonynya tidak mampu menjawab ketika masyarakat tersebut dihadapkan dengan 2 (dua) realitas objektif yang berbeda, dan menuntut perbedaan objektivasi dan eksternalisasi pula. Maka dari itu, teori adaptasi struktur Giddens bisa menjawab proses perubahan objektivasinya. Pandangan dalam teori Sosialisasi, dan sosialiasi politik di level praktikal dalam masyarakat Baduy perlu mempertimbangkan pandangan penggunaan kekuasaan. Ini karena struktur masyarakat Baduy memiliki cara yang berbeda dalam mengobjektivasi pengetahuannya.

Penelitian ini juga menegaskan tidak ditemuinya aturan pikukuh sapuluh seperti yang ada pada penelitian sebelumnya yang dilakukan oleh Yulianti (2006). Peneliti justru hanya menemukan aturan adat pikukuh karuhun. Namun penelitian ini juga menemukan hal yang serupa dengan penelitian sebelumnya yang dilakukan oleh Fernandez (2000) dan Yulianti (2006), yaitu tentang proses transferisasi atau transmisi pengetahuan dilakukan oleh tetua adat, teman bermain, lingkungan, dan keluarga melalui pola pengasuhan. Pada penelitian ini ditemukan bahwa proses sosialisasi pemilu dilakukan mulai dari keluarga. Berbeda dengan penelitian yang dilakukan oleh Fernandez (2000) yang menyatakan bahwa ibu memainkan peranan sentral dalam transmisi pengetahuan tersebut, penelitian ini menemukan peran ayah sebagai kepala keluarga yang menjadi agen sosialisasi pemilu. Selain itu, temuan akan adanya peluang untuk perubahan pada tradisi adat Baduy pada penelitian tersebut, juga ditemui pada penelitian ini. Bahkan tindakan-tindakan perubahan tersebut sangat jelas tergambar pada proses dan bentuk fresh act karena adanya dualisme struktur pada masyarakat Baduy. 


\section{Saran}

Oleh karena itu, penelitian berikutnya yang menggunakan teori Konstruksionis Sosial atau paradigma Sosiokultural diharapkan menelaah bagaimana peran jaro pamarentah mengonstruksi realitas dirinya untuk kemudian ia rekonstruksikan kepada anggota masyarakatnya karena perannya di dua struktur (struktur adat dan negara). Penelitian dengan perspektif Postmodernisme dapat dipakai untuk melihat kapital apa yang paling menentukan dalam perubahan budaya masyarakat Baduy untuk melengkapi perspektif Adaptasi Struktur Giddens.

\section{DAFTAR PUSTAKA}

\section{Buku:}

Badan Perencanaan dan Pembangunan Nasional (BAPPENAS), Badan Pusat Statistik (BPS), United Nation for Development Programs (UNDP). (2010). Indeks Demokrasi Indonesia, Jakarta: BAPPENAS.

Berger L, Peter and Thomas Luckmann. (1967). The Social Contruction of Reality: A Treatise in Sociology of Knowledge. New York: Anchor Books. Craig, Robert T and Heidi L, Muller. (2007). Theorizing Communication: Reading Accross Traditions. London, Thousand Oaks, CA., New Delhi: Sage Publications.

Henn, Matt, Mark Weinstein, and Nick Foard. (2006). A Short Introduction To Social Research. India: Sage Publications, Inc.

Kurnia, Asep dan Ahmad, Sihabudin. (2010). Saatnya Baduy Bicara. Jakarta: Bumi Aksara.

Littlejohn, Stephen., dan Karen A, Foss. (2011). Theories of Human Communication, tenth edition. Belmont, California: Thomson Wadsworth.

Moustakas, Clark. (1994). Phenomenological Research Methods. California : Sage Publication, Inc.

Nimmo, Dan. (1989). Komunikasi Politik Khalayak dan Efek. Bandung: PT Remaja Rosda Karya.
Patton, Quinn Michael. (2002). Qualitative Research Evaluation Methods, third edition. Thousand Oak: Sage Publication, Inc.

Poole, et.al. (1996). The Structuration of Group Decisions, in Hirokawa and Poole (Eds.), Communication and Group Decision Making, $2^{\text {nd }}$ Edition (pp 114-146). Beverly Hills, California: Sage Publication, Inc.

Rush, Michael and Phillip Althoff. Sosiologi Politik (alih bahasa Kartini Kartono, 2003). Jakarta: Rajawali Pers.

Saukko, P. (2003). Doing Research in Cultural Studies: An Introduction to Classical and New Methodological Approaches. London: Sage Publications, Inc.

West, Richard dan Lynn Turner. (2007). Introducing Communication Theory, Analysis and Application. New York: McGraw-Hill.

Tesis:

Fernandez, Daniel. (2000). Transmisi Pengetahuan Masyarakat Tradisional (Studi Pola Pengasuhan Anak Baduy di Dusun Gajeboh, Desa Kanekes, Kabupaten Lebak, Jawa Barat. Tesis. FISIP UI.

Yulianti, Iis. (2006). Coordinated Management of Meaning Nilai Budaya pada Suku Baduy (Kajian Etnografi Teks Pikukuh Karuhun pada Generasi Muda Suku Baduy di Desa Kanekes). Tesis. Ilmu Komunikasi FISIP UI.

\section{Makalah:}

Eberle, Thomas Samuel. A New Paradigm For The Sociology of Knowledge: "The Social Construction of Reality" After 25 Years". "Schweiz. Z. Soziol./Rev.suisse social. (1992) 493-502.

Hidayat, Dedy N. Paradigma Dan Metodologi Penelitian. (2002, 20-23 Agustus). Makalah disampaikan pada Pelatihan Riset Komunikasi di Pusat Kajian Komunikasi Fakultas Ilmu Sosial Ilmu Politik- Universitas Indonesia Depok. 


\section{Internet:}

Komisi Pemilihan Umum. (2014). Daftar Pemilihan Tetap. Tersedia dalam http://www.kpu.go.id, diakses tanggal 27 Januari 2014. 